\title{
RESERVOIR'S IMPACT ON THE WATER CHEMISTRY OF THE TEESTA RIVER MOUNTAIN COURSE (DARJEELING HIMALAYA)
}

\author{
WPLYW ZBIORNIKA NA CHEMIZM WODY GÓRSKIEGO \\ BIEGU RZEKI TISTY (DARDŻYLIŃSKIE HIMALAJE)
}

\begin{abstract}
The article presents the role of the newly built reservoir in the formation of the hydrochemistry of water of the Teesta River (a tributary of the Brahmaputra) in its Himalayan course. Field research were performed in the post-monsoon season of the period 2013-2015. Sampling and measuring points were located in five points over $43 \mathrm{~km}$ of the Teesta River in the Darjeeling Himalaya. Analysis of water along of river longitudinal profile above and below the reservoir suggest that the reservoir caused decrease most of the basic ions concentrations $\left(\mathrm{Cl}^{-}, \mathrm{K}^{+}\right.$, $\mathrm{Na}^{+}, \mathrm{Mg}^{2+}, \mathrm{NO}_{3}^{-}$and $\left.\mathrm{PO}_{4}{ }^{3-}\right)$. An inverse trend was observed only with respect to $\mathrm{Ca}^{2+}, \mathrm{SO}_{4}{ }^{2-}$ and $\mathrm{NH}_{4}^{+}$. The dam does not influent on the $\mathrm{F}^{-}$concentration. The reservoir causes minor enrichment most of the heavy metals such $\mathrm{Cu}, \mathrm{Ni}, \mathrm{Zn}, \mathrm{Cr}, \mathrm{Cd}$ and $\mathrm{Sr}$. The lower enrichment of Teesta water below the dam indicates the water self-purification processes for metals by the Teesta Reservoir. The changes of physicochemical properties and concentrations of ions caused by the reservoir are usually normalised by environmental factors before the Teesta River outlet from the Himalayas (within $15 \mathrm{~km}$ of the river).
\end{abstract}

Keywords: water chemistry, water quality, dam reservoir, Teesta River, Himalayas

\section{Introduction}

The chemical composition of water in rivers influence the water quality and determine its suitability for agricultural, domestic and industrial uses [1-3]. Physicochemical properties of water are one of the main factors affecting the proper functioning of river ecosystems [4]. The chemical composition of natural water is derived from many different sources of solutes, including gasses and aerosols from the atmosphere, weathering and erosion of rocks/soil, solution or precipitation reactions occurring below the land surface, and anthropogenic effects resulting from human activities $[5,6]$.

A very important role in the shaping of chemical composition and physicochemical parameters of the river systems also play reservoirs [6-10]. The chemical composition of

\footnotetext{
${ }^{1}$ Institute of Geography and Spatial Organization, Polish Academy of Sciences, ul. św. Jana 22, 31-018 Kraków, Poland, email: wieja@zg.pan.krakow.pl

${ }^{2}$ Jan Kochanowski University, Department of Environment Protection and Modelling, ul. Świętokrzyska 15, 25-406 Kielce, Poland

${ }^{3}$ Geography Department, North Bengal University, 734430 - Siliguri, India

*Corresponding author: wieja@zg.pan.krakow.pl
} 
stream water entering a reservoir usually undergoes significant chemical change during impoundment, and these changes can be observed in the outflow at the dam. The physicochemical properties of the water running out of the reservoir reflect the quality of the water entering it, the biotic and abiotic phenomena in the reservoir and operational variables such as the depth at which the outlet lies and regulation of water outflow [11]. River damming has a particular impact on the chemical composition of water, in the cases of reservoirs with longer residence times [6,7]. According to [12] in general, small dams caused low-intensity chemical changes which recovered within $3 \mathrm{~km}$, but larger dams caused larger disturbances which took up to $30 \mathrm{~km}$ to recover. The downstream effects of impoundments with low level outlets were more severe than water releases from the surface.

Reservoirs can improve water quality because the relatively slow water flow compared with rivers allows for the sedimentation of suspended material and the occurrence of processes such as denitrification and phosphorus diminution. The presence of reservoirs could be considered as a depuration system of the water quality $[13,14]$.

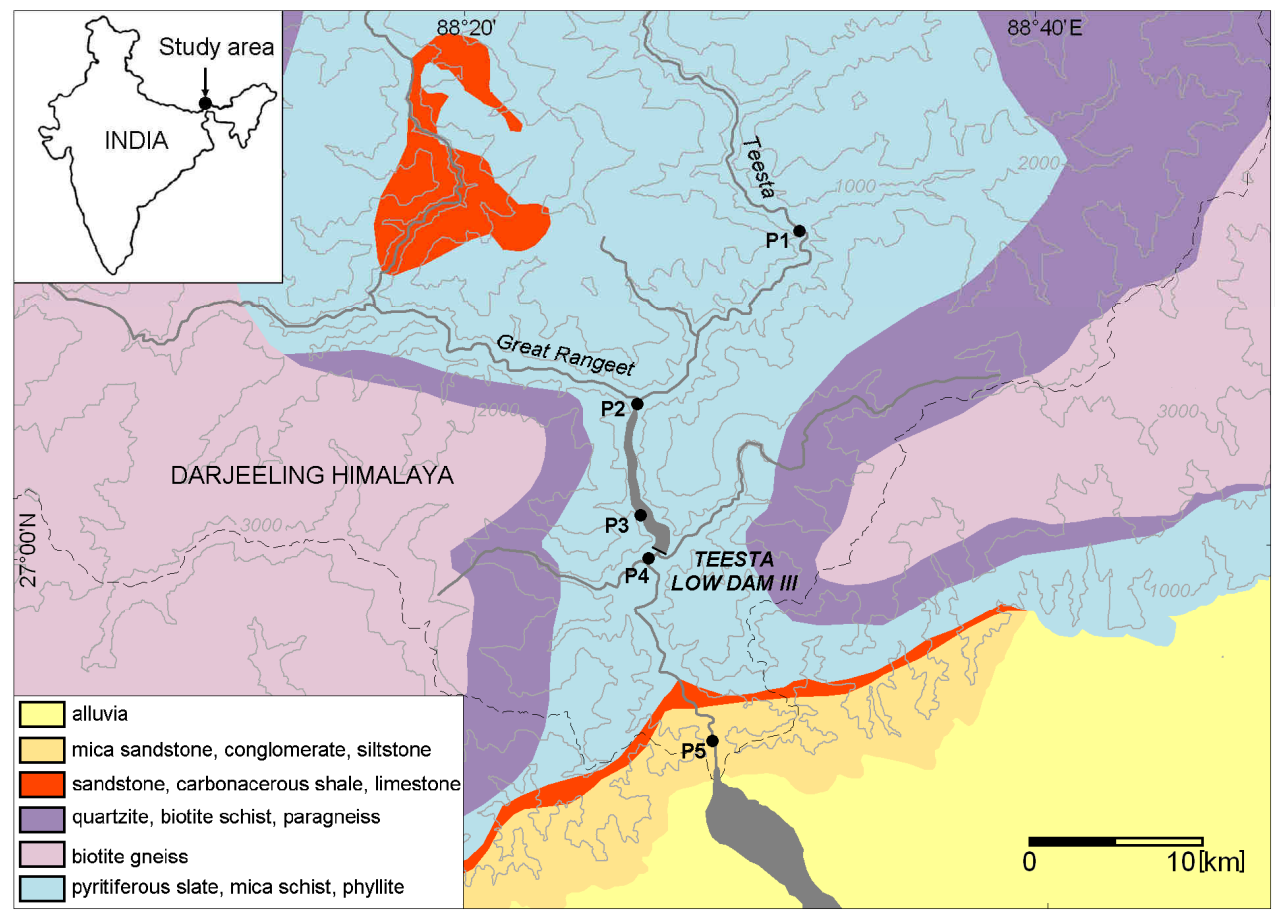

Fig. 1. Study area and location of water sampling points

In light of a growing demand for energy, the government of India has decided to double the current energy production with the use of the potential of rivers by building numerous hydroelectric plants. One of the regions in which such plants are being built is the Teesta River Basin - right tributary of the Brahmaputra [15]. Building numerous dams and reservoirs within one catchment can lead to significant transformations of the natural 
environment, including hydrochemical changes that determine water quality. In April 2013, one of the planned projects was completed: Teesta Low Dam-III located at Kalimpong, Darjeeling, West Bengal. The total capacity of the hydropower plant is $132 \mathrm{MW}$. The main task of the project is to harness the hydropower potential of the Teesta River. The dam is $32.5 \mathrm{~m}$ high.

The main aim of undertaken research and analysis was to verify whether the creation of the reservoir changed the chemical composition and physicochemical parameters of water in the Teesta River in its Himalayan course (Fig. 1). The basic problem undertaken to explain in this article is the direction, scale and scope of the impact of the reservoir on the hydrochemistry of the water in the river.

\section{Study area}

The Teesta River is the right tributary of the Brahmaputra. It is $414 \mathrm{~km}$ long (the catchment area is $\left.12159 \mathrm{~km}^{2}\right)$, about $200 \mathrm{~km}$ of which $\left(8051 \mathrm{~km}^{2}\right)$ is mountain area within the Sikkim-Darjeeling Himalaya. The Teesta River originates from a glacial lake at an elevation of $5280 \mathrm{~m}$. The eastern tributaries of the Teesta River within the mountains are shorter in course but larger in number, whereas the western tributaries are much longer with larger drainage areas, consequently contributing much more amount of water to the Teesta River. Furthermore, right-bank tributaries drain heavily glaciated areas with large snow-fields. The left bank tributaries, on the other hand, originate from semi-permanent and much smaller snow-fields as compared to right bank tributaries [16]. The main tributary of the river is the Great Rangeet which meets the river in Teesta Bazar. After it joins with the Great Rangeet, the Teesta River alters its course from south-west to south-east, and does not change its direction until it flows to the Brahmaputra in Bangladesh.

The hydrological regime of the Teesta River is complex - the river is supplied with waters from melting snow and ice, underground waters and very high rainfall, the annual sum of which reaches $4000-6000 \mathrm{~mm}$ at the margin of the Himalaya and decreases to $3000 \mathrm{~mm}$ in Sikkim [17-19]. The mean annual discharge of the Teesta nearly $45 \mathrm{~km}$ downstream from the Himalaya margin is about $600 \mathrm{~m}^{3} \cdot \mathrm{s}^{-1}$. Average monthly discharges during summer monsoon reach $1500 \mathrm{~m}^{3} \cdot \mathrm{s}^{-1}$ and it declines to $120 \mathrm{~m}^{3} \cdot \mathrm{s}^{-1}$ in the dry season [20]. The peak estimated during 1968 devastating flood exceeded $18000 \mathrm{~m}^{3} \cdot \mathrm{s}^{-1}$ [21].

From the geological point of view (which is significant for a hydrochemical analysis of surface waters), the upper Teesta River, in the Darjeeling-Sikkim Himalaya, is situated in the eastern part of the Himalayas. The eastern, northern, and western parts of the Teesta catchment are covered by Precambrian sillimanite gneisses and leucogranites belonging to the Tibetan Tethys Himalayan and Higher Himalayan zones. The central and southern portions are composed of Carboniferous-Permian metasedimentary rocks (slate, phyllite, and schist) of the Lesser Himalayan zone. The southern part of the Himalayan front consists of Mio-Pliocene mollase deposits of the Siwaliks [22, 23].

Most of the mountainous Teesta catchment is covered by forest. This changes from moist deciduous up to $1000 \mathrm{~m}$ a.s.l., through tropical evergreen forest up to $2000 \mathrm{~m}$ a.s.l. and a pure Rhododendron stand between 2500 and $2800 \mathrm{~m}$ a.s.1., to temperate coniferous at elevations of 3 000-3 $500 \mathrm{~m}$ a.s.l. The upper part of the catchments is covered by sub-alpine fir forest, which gradually changes to alpine grassland above the upper timberline at approximately $4000 \mathrm{~m}$ a.s.l. [24]. The perpetual snow line is found above 
$5300 \mathrm{~m}$ a.s.l. The southern margin of the Teesta catchment is densely populated and human impact on the environment (rice and tea cultivation) is more visible here than in the upper part of the Sikkim Himalaya [25]. The assessment of the hydromorphological state of the Teesta River showed that the river sections without noticeable human interference are characterized by sufficient habitat quality. Sections of the river with noticeable human interference i.e. river bank modifications, located mainly near bridges, are characterized by small or considerable modifications of the river habitat [26].

\section{Methods}

Field work, which consisted in measuring physicochemical parameters of water and collecting water samples for a chemical composition analysis, were conducted in three times during post-monsoon season (at the turn of November and December) between 2013 and 2015. They were carried out in a dry. The measurements were taken between 12 and $3 \mathrm{pm}$ (local time) when air temperature was the highest. Sampling and measuring points were located in five points over $43 \mathrm{~km}$ of the Teesta River in the Darjeeling Himalaya between the border of Sikkim and West Bengal, and the southern front of the Himalayas (Fig. 1). Above the newly built reservoir, the measurements were taken at two points (P1 and P2). Within the reservoir, the measurements and water sampling were conducted in the centre of the reservoir ( $\mathrm{P} 3$ at the bank). Two points were located below the dam (P4 and P5).

Water temperature, $\mathrm{pH}$ and conductivity were measured with the use of a $\mathrm{pH}$ meter and conductometer in the field. The analyses of the main ions were conducted in a laboratory with the use of an ion chromatography system (ICS 3000 by DIONEX). The concentrations of metals in the samples were determined with the use of an ICP-MS-TOP spectrometer by GBC. Before starting the analysis samples are filtered through a glass fiber (Whatman glass microfiber GF/D). Cations $\left(\mathrm{Ca}^{2+}, \mathrm{Mg}^{2+}, \mathrm{K}^{+}, \mathrm{Na}^{+}, \mathrm{NH}_{4}{ }^{+}, \mathrm{Li}^{+}\right)$and anions $\left(\mathrm{Cl}^{-}, \mathrm{SO}_{4}{ }^{2-}, \mathrm{NO}_{3}{ }^{-}\right)$ determined by ion chromatography (ICS3000 DIONEX), used an analytical column IonPac CS16 3x250 mm (cations) and IonPac AS18 2x250 mm (anions). Limits of detection were: $\mathrm{Ca}^{2+}-0.4 \mathrm{mg} \cdot \mathrm{dm}^{-3}, \mathrm{Mg}^{2+}, \mathrm{Na}^{+}, \mathrm{NH}_{4}^{+}, \mathrm{Li}^{+}-0.2 \mathrm{mg} \cdot \mathrm{dm}^{-3}, \mathrm{~K}^{+}-0.1 \mathrm{mg} \cdot \mathrm{dm}^{-3}$. Trace elements (Al, As, $\mathrm{Cd}, \mathrm{Co}, \mathrm{Cr}, \mathrm{Cu}, \mathrm{Fe}, \mathrm{Mn}, \mathrm{Ni}, \mathrm{Pb}, \mathrm{Sr}$ and $\mathrm{Zn}$ ) were determined by the ICP MS TOF spectrometer (OptiMass 9500 GBC). A multi-element standard (CLMS-2AN) working solution with the elements to be analyzed at a concentration of $10 \mu \mathrm{g} \cdot \mathrm{dm}^{-3}$ was prepared by stock solutions. All solutions were $1 \% \mathrm{v} / \mathrm{v}$ in nitric acid. For calibration, multi-element solutions were prepared with the following concentrations: 0 (blank), 1, 10, 50,100 and $1000 \mu \mathrm{g} \cdot \mathrm{dm}^{-3}$. The values of the highest concentrations of the models used for calibration were approved as a linear limits of the signal dependence on the concentration. Bicarbonates $\left(\mathrm{HCO}_{3}^{-}\right)$determined by the titration.

A ionic (charge) balance error expressed as the difference between cations and anions charges divided by their sum and multiplied by $100 \%$ did not exceed $10 \%$. Table 1 shows heavy metals concentrations, determined in the certified reference materials as ERM CA713 prepared by the Institute of Reference Materials and Measurements, Belgium using be mass spectrometer ICP-MS-TOF. Table 2 presents concentrations, determined in the certified reference materials as KEIJM-02 prepared by Environment Canada using by ion chromatography ICS 3000 DIONEX. 
Comparision of measured and certified concentrations in ERM CA713

\begin{tabular}{|c|c|c|c|c|c|}
\hline \multirow{3}{*}{ Analyte } & \multicolumn{2}{|c|}{ ERM CA713 } & \multicolumn{2}{|c|}{ ICP MS TOF } & \multirow{2}{*}{ Dev. ${ }^{* *}$} \\
\hline & Concentration & \pm Uncertainty & Concentration & $\pm S D^{*}$ & \\
\hline & \multicolumn{4}{|c|}{$\left[\mu \mathrm{g} \cdot \mathrm{dm}^{-3}\right]$} & {$[\%]$} \\
\hline As & 10.8 & 0.3 & 11.4 & 2.4 & 5.5 \\
\hline $\mathrm{Cd}$ & 5.1 & 0.2 & 5.0 & 3.5 & -2.0 \\
\hline $\mathrm{Cr}$ & 20.9 & 1.3 & 22.0 & 3.1 & -5.0 \\
\hline $\mathrm{Cu}$ & 101.0 & 7.0 & 99.3 & 2.2 & -1.7 \\
\hline $\mathrm{Fe}$ & 445 & 27 & 454.0 & 2.0 & 2.0 \\
\hline $\mathrm{Mn}$ & 95.0 & 4.0 & 92.8 & 2.4 & -2.4 \\
\hline $\mathrm{Ni}$ & 50.3 & 1.4 & 48.8 & 2.8 & -3.1 \\
\hline $\mathrm{Pb}$ & 49.7 & 1.7 & 50.8 & 2.7 & 2.2 \\
\hline
\end{tabular}

* - standard deviation; ${ }^{*}$ - relative difference between the measured and certified concentration $100 \% \cdot\left(c_{z}-c_{c}\right) / c_{c}$

Comparision of measured and certified concentrations in KEIJM-02

\begin{tabular}{|c|c|c|c|c|c|}
\hline \multirow{3}{*}{ Analyte } & \multicolumn{2}{|c|}{ KEIJM-02 } & \multicolumn{2}{|c|}{ ICS 3000} & \multirow{2}{*}{ Dev. ${ }^{* *}$} \\
\hline & Concentration & \pm Uncertainty & Concentration & $\pm S D^{*}$ & \\
\hline & \multicolumn{4}{|c|}{$\left[\mathrm{mg}^{2} \mathrm{dm}^{-3}\right]$} & {$[\%]$} \\
\hline $\mathrm{Ca}^{2+}$ & 0.852 & 0.085 & 0.8 & 1.4 & -4.9 \\
\hline $\mathrm{Mg}^{2+}$ & 0.467 & 0.038 & 0.5 & 1.1 & -2.0 \\
\hline $\mathrm{K}^{+}$ & 0.224 & 0.032 & 0.2 & 0.9 & 4.3 \\
\hline $\mathrm{Na}^{+}$ & 3.80 & 0.32 & 3.7 & 1.3 & -2.2 \\
\hline $\mathrm{Cl}^{-}$ & 5.79 & 0.41 & 5.7 & 0.8 & -1.9 \\
\hline $\mathrm{SO}_{4}{ }^{2-}$ & 2.420 & 0.038 & 2.3 & 2.2 & -3.0 \\
\hline
\end{tabular}

* - standard deviation; ${ }^{* *}$ - relative difference between the measured and certified concentration $100 \% \cdot\left(c_{z}-c_{c}\right) / c_{c}$

The water samples were tested for the presence of the following cations: $\mathrm{Na}^{+}, \mathrm{K}^{+}, \mathrm{Ca}^{2+}$, $\mathrm{Mg}^{2+}, \mathrm{NH}_{4}{ }^{+}$, and anions $\mathrm{Cl}^{-}, \mathrm{SO}_{4}{ }^{2-}, \mathrm{HCO}_{3}{ }^{-}, \mathrm{NO}_{3}{ }^{-}, \mathrm{F}^{-}, \mathrm{PO}_{4}{ }^{3-}$ as well as heavy metals: $\mathrm{Fe}, \mathrm{Al}$, $\mathrm{Sr}, \mathrm{Ni}, \mathrm{Zn}, \mathrm{Cu}, \mathrm{Cr}, \mathrm{Co}, \mathrm{Mn}, \mathrm{Cd}$ and $\mathrm{Pb}$.

The indicator of the ecochemical status of the water, i.e. the volume of acid neutralising capacity, ANC, was calculated using formula $\left(\mathrm{K}^{+}+\mathrm{Na}^{+}+2 \mathrm{Mg}^{2+}+2 \mathrm{Ca}^{2+}-\mathrm{NO}_{3}{ }^{-}-\right.$ $\mathrm{Cl}^{-}-2 \mathrm{SO}_{4}{ }^{2-}$ ). The ANC delivers information on the degree of sensitivity of surface waters to acidification [27, 28]. Acid neutralizing capacity of natural waters is widely measured as a key water quality parameter in both regional water quality surveys and intensive watershed studies. ANC is generally regarded as a more suitable index of a natural water's acid-base status than $\mathrm{pH}$ because it is considered not to vary with transient (e.g., diurnal) changes in total inorganic carbon content [29]. These indicator have been used to evaluate the degree of acidification of rainfall, throughfall and stemflow as well as surface waters [28, 30-34].

A better understanding of water heavy metal concentrations due to dam construction may give calculation of enrichment factor $(E F)$. The concept of $E F$ is used to evaluate the anthropogenic impact. The $E F$ was calculated for the Teesta Reservoir using the following equation [35]:

$$
E F=\left(C_{x} / C_{b}\right)_{\text {sample }} /\left(C_{b} / C_{x}\right)_{\text {reference material }}
$$

Equation is the ratio of the concentration of the examined element $\left(C_{x}\right)$ to the reference element $\left(C_{b}\right)$ in the sample and reference material, respectively. In this study, Fe was used as the reference element because it mainly originates from natural lithogenic sources, its 
distribution is not related to other heavy metals and this element is commonly used as reference element in the assessment of $E F[35,36]$. The levels of heavy metal pollution were interpreted according to [37] with $E F<1.50$ as no enrichment, $1.50<E F<3.00$ as minor enrichment, and $3.00<E F<5.00$ as moderate enrichment.

The values of the basic parameters and physicochemical indicators as well as concentrations of individual ions presented in the paper are arithmetic mean values of the data from measurements taken in the three post monsoon periods in the years 2013-2015.

\section{Results and discussion}

\section{The changes of physicochemical parameters in the longitudinal profile of the Teesta River}

The temperature of the Teesta River above the reservoir shows a natural increase with the course of the river. At the beginning of the research section analysed, the temperature amounted to $14.9^{\circ} \mathrm{C}$. It was higher by $1.4^{\circ} \mathrm{C}$ approximately $17 \mathrm{~km}$ further, at the margin of the river and reservoir's backwater (Fig. 2, Table 3). The impact of the newly built reservoir on water temperature is noticeable, but the range of changes caused by the reservoir is not considerable. Below the dam, the temperature of the Teesta River was lower by only $0.9^{\circ} \mathrm{C}$ compared to the river above the reservoir $\left(16.3^{\circ} \mathrm{C}\right)$ and by $1.9^{\circ} \mathrm{C}$ compared to the water in the reservoir. A low range of changes indicates that a very weak thermal stratification has developed due to the rapid exchange of water in the reservoir. The temperature of water in the Teesta River flowing out of the Himalaya was $17.4^{\circ} \mathrm{C}$, so after approximately $15 \mathrm{~km}$, the differences caused by the presence of the reservoir were normalised by the thermal conditions of the environment.

The Teesta water is alkaline in nature. The water $\mathrm{pH}$ values range between 8.1-8.3 and show slight decrease of alkalinity on the river section above and below reservoir but in the reservoir and in water flowing out of it the values of $\mathrm{pH}$ were somewhat higher (Fig. 2, Table 3).

The ANC values demonstrated that the water in the entire section of the Teesta River and in the reservoir do not show any acidification hazard. The values of this indicator ranged on average from $1,429-1,561 \mu \mathrm{eq} \cdot \mathrm{dm}^{-3}$ (Fig. 2, Table 3). ANC $>0$ indicates that surface waters have a direct contact with the solid phase of soil saturated with bases, and the content of aluminium and iron ions is low. This proves that these waters show no acidification hazard irrespective of "land development". There is no risk of a reduction in the number of living organisms or water acidification. According to [30], a decrease in the ANC value may contribute to a reduction in the number of living organisms in the water. Sullivan et al. [33] report that the ANC value ranged from 60 to $102 \mu \mathrm{eq} \cdot \mathrm{dm}^{-3}$ in granitic watersheds, and from 126 to $258 \mu \mathrm{eq} \cdot \mathrm{dm}^{-3}$ in basaltic watersheds.

The total dissolved solids (TDS) show decrease of values from $88.66 \mathrm{mg} \cdot \mathrm{dm}^{-3}$ in Sikkim to $80.44 \mathrm{mg} \cdot \mathrm{dm}^{-3}$ in water below connection with Rangeet and then slight increase of mineralization in reservoir as well as water flowing out of it to the level $84.97-85.95 \mathrm{mg} \cdot \mathrm{dm}^{-3}$ which remain to the outlet of the river from the Himalayas (Fig. 2, Table 3). 

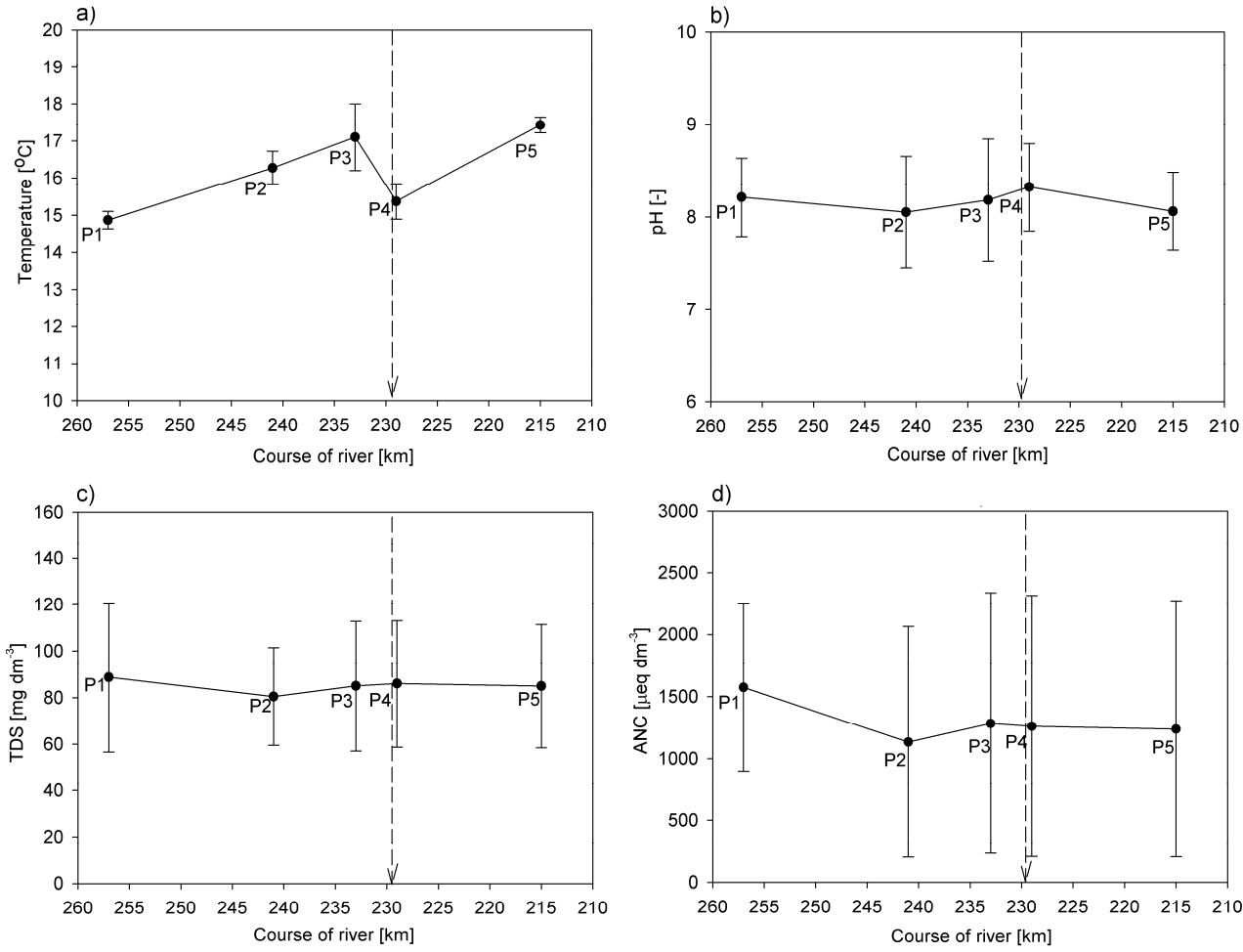

Fig. 2. Average values of water: a) temperature, b) $\mathrm{pH}, \mathrm{c}$ ) TDS and d) ANC in the longitudinal profile of the Teesta River between Sikkim and the margin of the Himalayas in the post-monsoon season of the period 2013-2015 (an arrow indicate the dam position)

Table 3

Physicochemical composition of water in the Teesta River between Sikkim and the margin of the Himalaya

\begin{tabular}{|c|c|c|c|c|c|c|c|c|c|c|}
\hline Parameters & P1 & SD & P2 & SD & P3 & SD & P4 & SD & P5 & SD \\
\hline $\mathrm{T}\left[{ }^{\circ} \mathrm{C}\right]$ & 14.9 & 0.2 & 16.3 & 0.5 & 17.10 & 0.90 & 15.4 & 0.5 & 17.4 & 0.2 \\
\hline $\mathrm{pH}[-]$ & 8.21 & 0.42 & 8.05 & 0.60 & 8.18 & 0.66 & 8.32 & 0.47 & 8.1 & 0.4 \\
\hline $\mathrm{Ca}^{2+}\left[\mathrm{mg} \cdot \mathrm{dm}^{-3}\right]$ & 14.6 & 6.5 & 12.0 & 4.0 & 13.4 & 4.7 & 13.9 & 5.8 & 13.5 & 5.3 \\
\hline $\mathrm{Mg}^{2+}\left[\mathrm{mg} \cdot \mathrm{dm}^{-3}\right]$ & 1.3 & 0.3 & 1.6 & 0.3 & 1.6 & 0.6 & 1.4 & 0.3 & 1.5 & 0.3 \\
\hline $\mathrm{Na}^{+}\left[\mathrm{mg} \cdot \mathrm{dm}^{-3}\right]$ & 5.4 & 3.5 & 5.8 & 3.5 & 5.8 & 4.3 & 5.1 & 3.4 & 5.7 & 3.1 \\
\hline $\mathrm{K}^{+}\left[\mathrm{mg} \cdot \mathrm{dm}^{-3}\right]$ & 1.4 & 0.4 & 1.4 & 0.2 & 1.2 & 0.3 & 1.6 & 0.3 & 1.5 & 0.2 \\
\hline $\mathrm{Cl}^{-}\left[\mathrm{mg} \cdot \mathrm{dm}^{-3}\right]$ & 1.6 & 1.2 & 1.6 & 0.5 & 1.2 & 0.5 & 1.0 & 0.3 & 1.7 & 1.2 \\
\hline $\mathrm{SO}_{4}{ }^{2-}\left[\mathrm{mg} \cdot \mathrm{dm}^{-3}\right]$ & 7.6 & 0.3 & 6.4 & 0.6 & 6.6 & 0.5 & 7.0 & 0.5 & 6.9 & 0.3 \\
\hline $\mathrm{F}^{-}\left[\mathrm{mg} \cdot \mathrm{dm}^{-3}\right]$ & 0.3 & 0.3 & 0.2 & 0.2 & 0.2 & 0.1 & 0.2 & 0.1 & 0.20 & 0.03 \\
\hline $\mathrm{NO}_{3}{ }^{-}\left[\mathrm{mg} \cdot \mathrm{dm}^{-3}\right]$ & 1.2 & 0.2 & 1.0 & 0.4 & 0.7 & 0.3 & 0.8 & 0.2 & 0.7 & 0.2 \\
\hline $\mathrm{HCO}_{3}{ }^{-}\left[\mathrm{mg} \cdot \mathrm{dm}^{-3}\right]$ & 55 & 23 & 50 & 15 & 54 & 21 & 55 & 20 & 53 & 19 \\
\hline $\mathrm{PO}_{4}{ }^{3-}\left[\mathrm{mg} \cdot \mathrm{dm}^{-3}\right]$ & 0.01 & 0.01 & 0.01 & 0.01 & 0.00 & 0.0 & 0.00 & 0.0 & 0.01 & 0.02 \\
\hline $\mathrm{NH}_{4}{ }^{+}\left[\mathrm{mg} \cdot \mathrm{dm}^{-3}\right]$ & 0.12 & 0.20 & 0.13 & 0.20 & 0.16 & 0.26 & 0.18 & 0.27 & 0.1 & 0.2 \\
\hline $\mathrm{TDS}_{\left.\mathrm{TDg} \cdot \mathrm{dm}^{-3}\right]}^{88.7}$ & 32.0 & 80 & 21 & 85 & 28 & 86 & 27 & 85 & 26 \\
\hline $\left.\mathrm{ANC}^{-3} \mathrm{meq} \cdot \mathrm{dm}^{-3}\right]$ & 1573 & 676 & 1133 & 932 & 1284 & 1052 & 1260 & 1054 & 1238 & 1035 \\
\hline
\end{tabular}

* - standard deviation 


\section{The changes of the chemical composition of water in the longitudinal profile of the Teesta River}

\section{Anions and cations}

The major anions for sampled sites are arranged in decreasing order as $\mathrm{HCO}_{3}{ }^{-}>\mathrm{SO}_{4}{ }^{2-}$ $>\mathrm{Cl}^{-}>\mathrm{NO}_{3}{ }^{-}>\mathrm{F}^{-}>\mathrm{PO}_{4}{ }^{3-}$. The average bicarbonate and sulphate concentrations account for $82 \%$ and $13 \%$ of the total anions in equivalent units respectively. Chloride constitutes about $3 \%$, while nitrate, phosphate and fluoride together account for only $2 \%$ of the total anions.

The analysis of the anions change in the longitudinal profile of the Teesta River (Fig. 1, Table 3) revealed that the newly built reservoir contributes to the decreasing of $\mathrm{Cl}^{-}$, $\mathrm{NO}_{3}{ }^{-}$and $\mathrm{PO}_{4}{ }^{3-}$, increasing of the $\mathrm{HCO}_{3}{ }^{-}$and $\mathrm{SO}_{4}{ }^{2-}$, while it not influent $\mathrm{F}^{-}$concentration.

$\mathrm{HCO}_{3}{ }^{-}$concentration decrease from 54.8 to $50.0 \mathrm{mg} \cdot \mathrm{dm}^{-3}$ between upper studied section and below the mouth of the Great Rangeet. In the water flowing out of the reservoir, the concentration increase to $54.6 \mathrm{mg} \cdot \mathrm{dm}^{-3}$ and again little falls to $53.0 \mathrm{mg} \cdot \mathrm{dm}^{-3}$ at the end of the section examined where the river exits the Himalayas. The high concentration of $\mathrm{HCO}_{3}{ }^{-}$is an indication of intense chemical weathering occurring in the drainage basin.

Above the reservoir, a decrease in the $\mathrm{SO}_{4}{ }^{2-}$ concentration was noted: from 7.6 to $6.4 \mathrm{mg} \cdot \mathrm{dm}^{-3}$ below the mouth of the Rangeet. In the water flowing out of the reservoir, the concentration increased to $7.1 \mathrm{mg} \cdot \mathrm{dm}^{-3}$, and a similar $\mathrm{SO}_{4}{ }^{2-}$ level was also found at the end of the section examined where the river exits the Himalayas. The concentrations of $\mathrm{SO}_{4}{ }^{2-}$ in the Teesta river presented in the study correlate with the content of $\mathrm{Ca}^{+}(r=0.91)$. This indicates its mainly natural origin from weathering of the pyritiferous slates [38]. Minor $\mathrm{SO}_{4}{ }^{2-}$ of anthropogenic origin (sewage) can contribute small triburaries from densely populated watersheds around reservoir.

The content of $\mathrm{Cl}^{-}$in the river above the reservoir was $1.6-1.7 \mathrm{mg} \cdot \mathrm{dm}^{-3}$. In the reservoir and in the water flowing out of it, the level decreased to $1.1-1.2 \mathrm{mg} \cdot \mathrm{dm}^{-3}$. At the outlet of the Teesta River from the Himalayas, the concentrations were similar to those observed above the reservoir. Very low $\mathrm{Cl}^{-}$concentration indicates its natural origin from atmospheric deposition of oceanic aerosols and with the weathering of igneous and some sedimentary rocks. Since chloride ions do not significantly enter into oxidation or reduction reactions their decreasing concentration in the reservoir is largely effect of physical processes.

The $\mathrm{F}^{-}$concentrations were low and ranged between $0.2-0.3 \mathrm{mg} \cdot \mathrm{dm}^{-3}$ along the entire section examined. Since there is no metal-and chemical-based manufacturing in the Teesta basin, fluoride in the river water was mainly contributed from runoff from the agriculture area.

The concentration of $\mathrm{NO}_{3}{ }^{-}$in the reservoir and in the water flowing out of it $\left(0.7-0.8 \mathrm{mg} \cdot \mathrm{dm}^{-3}\right)$ was lower than in the water above the reservoir $\left(1.0-1.2 \mathrm{mg} \cdot \mathrm{dm}^{-3}\right)$. A substantial reduction in the inorganic nitrate concentrations in the reservoir indicates its denitrification mainly in biological processes.

The major cations for all sampling sites generally follow decreasing order as $\mathrm{Ca}^{2+}>$ $\mathrm{Na}^{+}>\mathrm{Mg}^{2+}>\mathrm{K}^{+}>\mathrm{NH}_{4}{ }^{+}$. Calcium and sodium accounts for 62 and $22 \%$ of the total cations in equivalent units respectively. Magnesium, potassium and ammonium are less predominant ions and together they account for only $16 \%$ of the total cations.

The analysis of the cations change in the longitudinal profile of the Teesta River (Fig. 1 , Table 3 ) revealed that the newly built reservoir contributes to the decreasing of $\mathrm{Na}^{+}, \mathrm{Mg}^{+}$ and $\mathrm{K}^{+}$concentration and increasing of the $\mathrm{Ca}^{2+}$ and $\mathrm{NH}_{4}^{+}$. 
The highest $\mathrm{Ca}^{2+}$ concentration in the Teesta River was observed at the beginning of the research section $\left(14.6 \mathrm{mg} \cdot \mathrm{dm}^{-3}\right)$ and it decreased markedly at the margin of the river and reservoir's backwater below the mouth of the Great Rangeet to $12.1 \mathrm{mg} \cdot \mathrm{dm}^{-3}$. The $\mathrm{Ca}^{2+}$ concentration increased to $13.4 \mathrm{mg} \cdot \mathrm{dm}^{-3}$ in the reservoir and to $13.9 \mathrm{mg} \cdot \mathrm{dm}^{-3}$ in the outlet. The $\mathrm{Ca}^{2+}$ concentration is attributed to weathering of carbonate and silicate minerals in the study area. The studies of [39-41] also indicate a high share of $\mathrm{Ca}^{2+}$ in the chemical composition of water in the rivers and reservoirs of the Brahmaputra basin and of the neighbouring areas.

$\mathrm{NH}_{4}{ }^{+}$was found in small amounts in all samples collected from the Teesta River. They, however, tended to increase along the longitudinal profile of the Teesta section examined from 0.12 to $0.18 \mathrm{mg} \cdot \mathrm{dm}^{-3}$. Increase of $\mathrm{NH}_{4}{ }^{+}$along with earlier described decrease of $\mathrm{NO}_{3}{ }^{-}$concentration, indicated reduction of nitrate to ammonia. However total ammonia concentrations do not exceed typical level for river water of $0.2 \mathrm{mg} \cdot \mathrm{dm}^{-3}$.

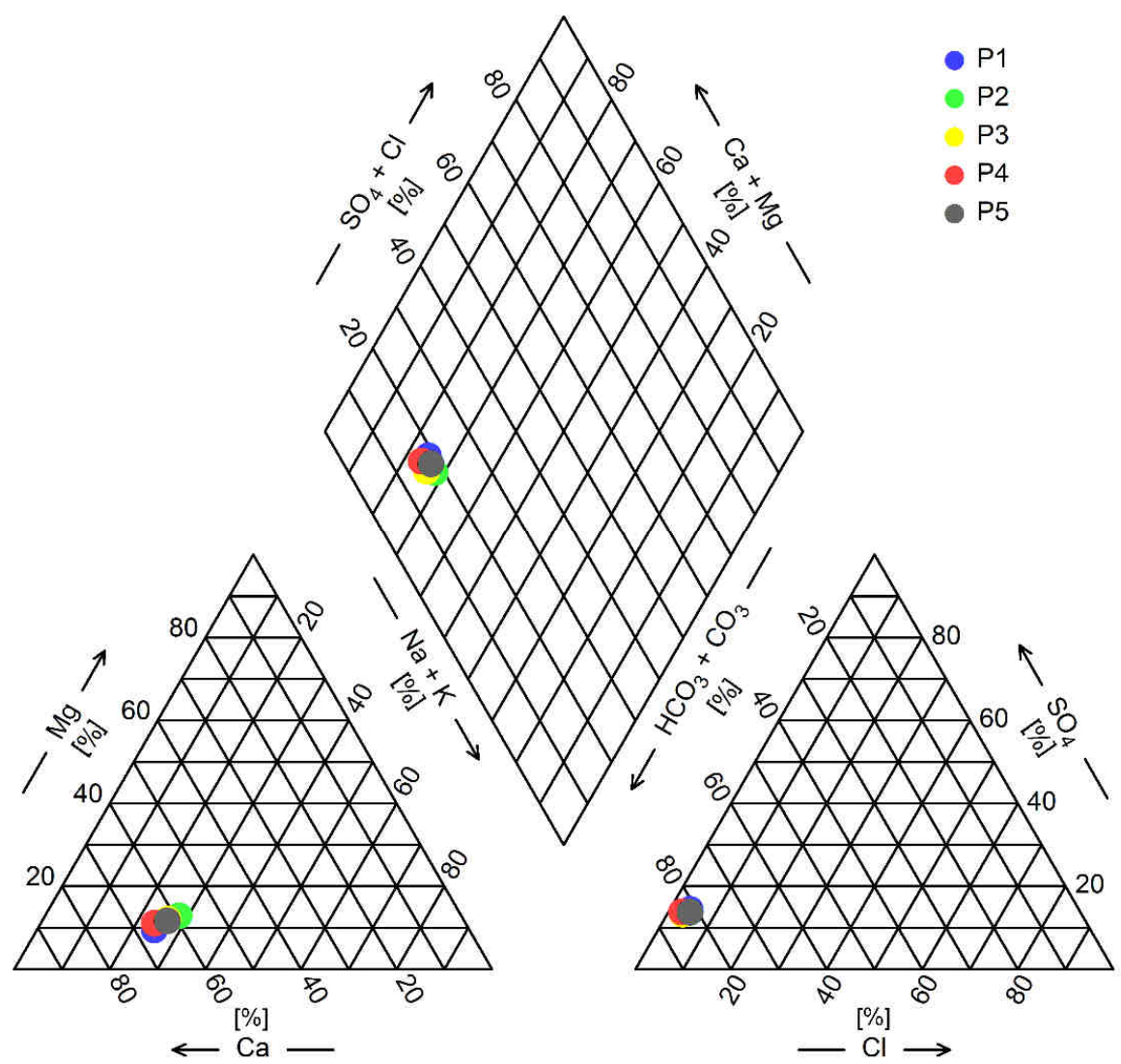

Fig. 3. The chemical composition of water for the Teesta River

The content of $\mathrm{K}^{+}$in the river above the reservoir was very low i.e. $1.4 \mathrm{mg} \cdot \mathrm{dm}^{-3}$. In the reservoir and in the water flowing out of it, the level decreased to $1.3 \mathrm{mg} \cdot \mathrm{dm}^{-3}$. At the 
outlet of the Teesta River from the Himalayas, the concentrations were similar to those observed above the reservoir. Potassium in Teesta river waters comes predominantly from weathering of silicate minerals both in metamorphic and sedimentary rocks. This suggest it is higher content above and below reservoir. In the reservoir potassium is readily taken by aquatic life and its content decrease.

The lowest concentration of $\mathrm{Na}^{+}$was observed in the water flowing out of reservoir $\left(5.1 \mathrm{mg} \cdot \mathrm{dm}^{-3}\right)$. At the end of the section tested, the concentration of these ions increased $\left(5.6 \mathrm{mg} \cdot \mathrm{dm}^{-3}\right)$ near to the level noted in the river above the reservoir. The main source of sodium in the Teesta was weathering of silicate minerals. Rainwater also can contribute little amounts of $\mathrm{Na}^{+}$through its deposition on soil surface especially in the southern part of catchment with high rainfall.

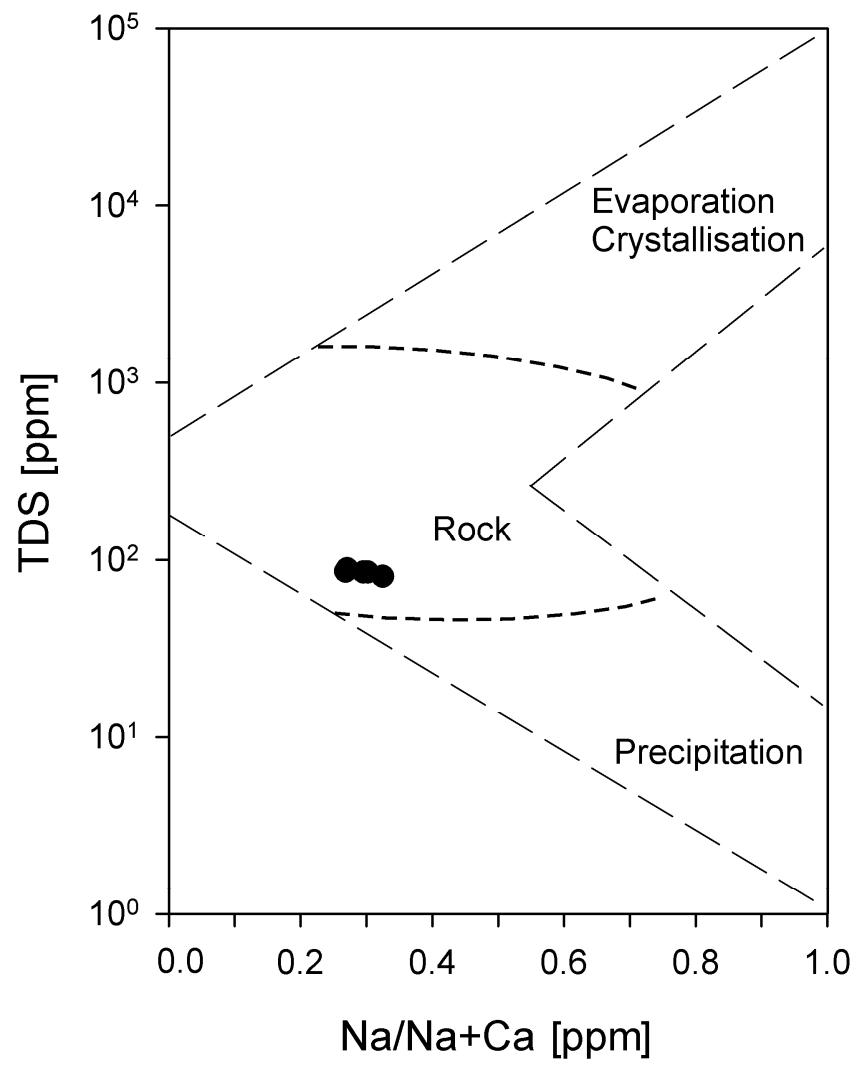

Fig. 4. Major factors controlling the water chemistry for the Teesta River

The content of $\mathrm{Mg}^{2+}$ above the reservoir increased from $1.3 \mathrm{mg} \cdot \mathrm{dm}^{-3}$ at the beginning of the section tested to $1.6 \mathrm{mg} \cdot \mathrm{dm}^{-3}$ below the mouth of the Rangeet. The reservoir decreased the concentration to $1.4 \mathrm{mg} \cdot \mathrm{dm}^{-3}$ and a similar level $\left(1.5 \mathrm{mg} \cdot \mathrm{dm}^{-3}\right)$ was observed in the remaining section of the river. The concentration of $\mathrm{Mg}^{2+}$ is generally low and its slightly changes along Teesta are mainly related to weathering of rocks containing ferromagnesium minerals and from some carbonate rocks. 
The chemical composition of Teesta water is also explained by plotting the major cations and anions in the Pipper diagram (Fig. 3) [42]. The diagram shows $\mathrm{Ca}^{2+}$ is dominant cation, and bicarbonate is the dominant anion explaining the water to be $\mathrm{Ca}-\mathrm{HCO}_{3}$ type. The water types between the upstream and downstream segments of Teesta as well as in the reservoir do not show distinctiveness in the Piper diagram. This suggests that chemical weathering of rocks and groundwater discharge are the most important mechanisms influencing the hydrochemistry in the Teesta. Similar conclusions were proved for Brahmaputra by Handique et al. [43].

The Gibbs plot (Fig. 4), [44] placing the Teesta samples in the region of rock dominance and to some extent by precipitation is consistent with the above observations and analysis for Brahmaputra basin [38]. The lithology in the basin consists of mostly biotite gneisses, granite gneisses, slates, schists, phyllites, sandstones and carbonacerous shales. Hence, the major sources of $\mathrm{Ca}$ should be the Ca-rich rocks. Even in silicate dominated terrains, most river water chemistry are found to be carbonic. This is due to the Ca-enriched soils and evaporites in addition to the Ca-derived from the silicate rock weathering.

\section{Heavy metals}

The mean values of metal concentrations along the Teesta can be arranged in order as $\mathrm{Fe}>\mathrm{Al}>\mathrm{Sr}>\mathrm{Zn}>\mathrm{Ni}>\mathrm{Cu}>\mathrm{Cr}>\mathrm{Mn}>\mathrm{Co}$ (Table 4, Fig. 5). The predominant $\mathrm{Fe}, \mathrm{Al}$ and Sr constituted approximately 88, 7 and $4 \%$ of the total concentration of heavy metals respectively. The $\mathrm{Pb}$, and $\mathrm{Cd}$ concentration values were below the detection limit at all sites.

However the concentration of individual heavy metals and its changes along the longitudinal profile of the river are highly diversified (Fig. 1, Table 4). Fe ions showed a decreased trend in their concentrations: from $240 \mu \mathrm{g} \cdot \mathrm{dm}^{-3}$ at the beginning of the research section to $192 \mu \mathrm{g} \cdot \mathrm{dm}^{-3}$ below the mouth of the Rangeet. In the reservoir and in the water flowing out of it, the concentrations increased to $220-221 \mu \mathrm{g} \cdot \mathrm{dm}^{-3}$ and similar level was observed at the end of the section analysed. The amount of $\mathrm{Al}$ ions decreased markedly at the margin of the river and reservoir's backwater below the mouth of the Rangeet $\left(12.2 \mu \mathrm{g} \cdot \mathrm{dm}^{-3}\right)$. Then, it increased in the water flowing out from the reservoir $\left(23.7 \mu \mathrm{g} \cdot \mathrm{dm}^{-3}\right)$ to the level observed above the Rangeet. Sr ions showed slightly different dynamics. A high concentration of $\mathrm{Sr}$ in the water of Himalayan rivers is a result of carbonate and silicate weathering [45]. Above the reservoir, the $\mathrm{Sr}$ amount increased with the course of the river from 11.0 to $17.3 \mu \mathrm{g} \cdot \mathrm{dm}^{-3}$. Although its concentration decreased in the reservoir $\left(13.8 \mu \mathrm{g} \cdot \mathrm{dm}^{-3}\right)$, a slight upward trend was observed again below the dam (from 13.8 to $15.3 \mu \mathrm{g} \cdot \mathrm{dm}^{-3}$ ).

The pattern of $\mathrm{Ni}, \mathrm{Zn}, \mathrm{Cu}, \mathrm{Cr}$ and $\mathrm{Mn}$ in the longitudinal profile of the river was similar. By contrast with $\mathrm{Fe}, \mathrm{Al}$ and $\mathrm{Sr}$, these ions were found in the Teesta River in only trace amounts. As for $\mathrm{Ni}$, the concentration of its ions decreased from 1.5 to $1.2 \mu \mathrm{g} \cdot \mathrm{dm}^{-3}$ and then increased to $1.7 \mu \mathrm{g} \cdot \mathrm{dm}^{-3}$ in the reservoir. It remained at a similar concentration up to the end of the section tested. The content of $\mathrm{Zn}$ in the river above the reservoir changed from 5.4 to $6.2 \mu \mathrm{g} \cdot \mathrm{dm}^{-3}$. It increased to $6.7 \mu \mathrm{g} \cdot \mathrm{dm}^{-3}$ in the reservoir and then demonstrated a slight upward trend below the dam (from 5.5 to $7.4 \mu \mathrm{g} \cdot \mathrm{dm}^{-3}$ ). The concentration of $\mathrm{Cu}$ also markedly increased in the reservoir and in the river below the dam $\left(0.9-1.1 \mu \mathrm{g} \cdot \mathrm{dm}^{-3}\right)$ compared to the Teesta River above the reservoir $\left(0.5-0.6 \mu \mathrm{g} \cdot \mathrm{dm}^{-3}\right)$. A decrease in the concentration in the river above the reservoir was also observed for Mn ions (from 0.03 to 
$\left.0.00 \mu \mathrm{g} \cdot \mathrm{dm}^{-3}\right)$. Subsequently, the values increased in the water flowing out of it and in the river at the exit of the Himalayas (to $0.04-0.05 \mu \mathrm{g} \cdot \mathrm{dm}^{-3}$ ). The amounts of Co and Cr were similar in all samples collected and amounted to $0.02-0.03 \mu \mathrm{g} \cdot \mathrm{dm}^{-3}$ and $0.5-0.7 \mu \mathrm{g} \cdot \mathrm{dm}^{-3}$, respectively.

Table 4

Heavy metals in the Teesta River between Sikkim and the margin of the Himalaya

\begin{tabular}{|c|c|c|c|c|c|c|c|c|c|c|}
\hline $\begin{array}{c}\text { Heavy } \\
\text { metals } \\
{\left[\boldsymbol{\mu g} \cdot \mathbf{d m}^{-3}\right]}\end{array}$ & $\mathbf{P 1}$ & $\boldsymbol{S D}^{*}$ & $\mathbf{P 2}$ & $\boldsymbol{S D}$ & $\mathbf{P 3}$ & $\boldsymbol{S D}$ & $\mathbf{P 4}$ & $\boldsymbol{S} \boldsymbol{D}$ & P5 & $\boldsymbol{S D}$ \\
\hline $\mathrm{Al}$ & 20 & 22 & 12.2 & 7.8 & 17 & 17 & 24 & 29 & 21 & 15 \\
\hline $\mathrm{Co}$ & 0.02 & 0.03 & 0.02 & 0.02 & 0.02 & 0.02 & 0.02 & 0.02 & 0.03 & 0.01 \\
\hline $\mathrm{Cr}$ & 0.59 & 0.32 & 0.52 & 0.15 & 0.56 & 0.24 & 0.49 & 0.28 & 0.66 & 0.27 \\
\hline $\mathrm{Cu}$ & 0.55 & 0.47 & 0.45 & 0.23 & 1.1 & 1.1 & 0.9 & 1.1 & 1.1 & 1.1 \\
\hline $\mathrm{Fe}$ & 240 & 174 & 192 & 136 & 220 & 153 & 221 & 158 & 224 & 159 \\
\hline $\mathrm{Mn}$ & 0.03 & 0.03 & 0.00 & 0.00 & 0.01 & 0.01 & 0.04 & 0.07 & 0.05 & 0.06 \\
\hline $\mathrm{Ni}$ & 1.51 & 0.97 & 1.2 & 1.0 & 1.7 & 1.5 & 1.5 & 1.3 & 1.7 & 1.5 \\
\hline $\mathrm{Sr}$ & 11.0 & 2.9 & 17.3 & 1.9 & 13.8 & 3.2 & 13.9 & 2.9 & 15.3 & 2.9 \\
\hline $\mathrm{Zn}$ & 5.4 & 7.1 & 6.2 & 9.8 & 6.7 & 8.5 & 5.5 & 7.3 & 7 & 10 \\
\hline
\end{tabular}

* - standard deviation

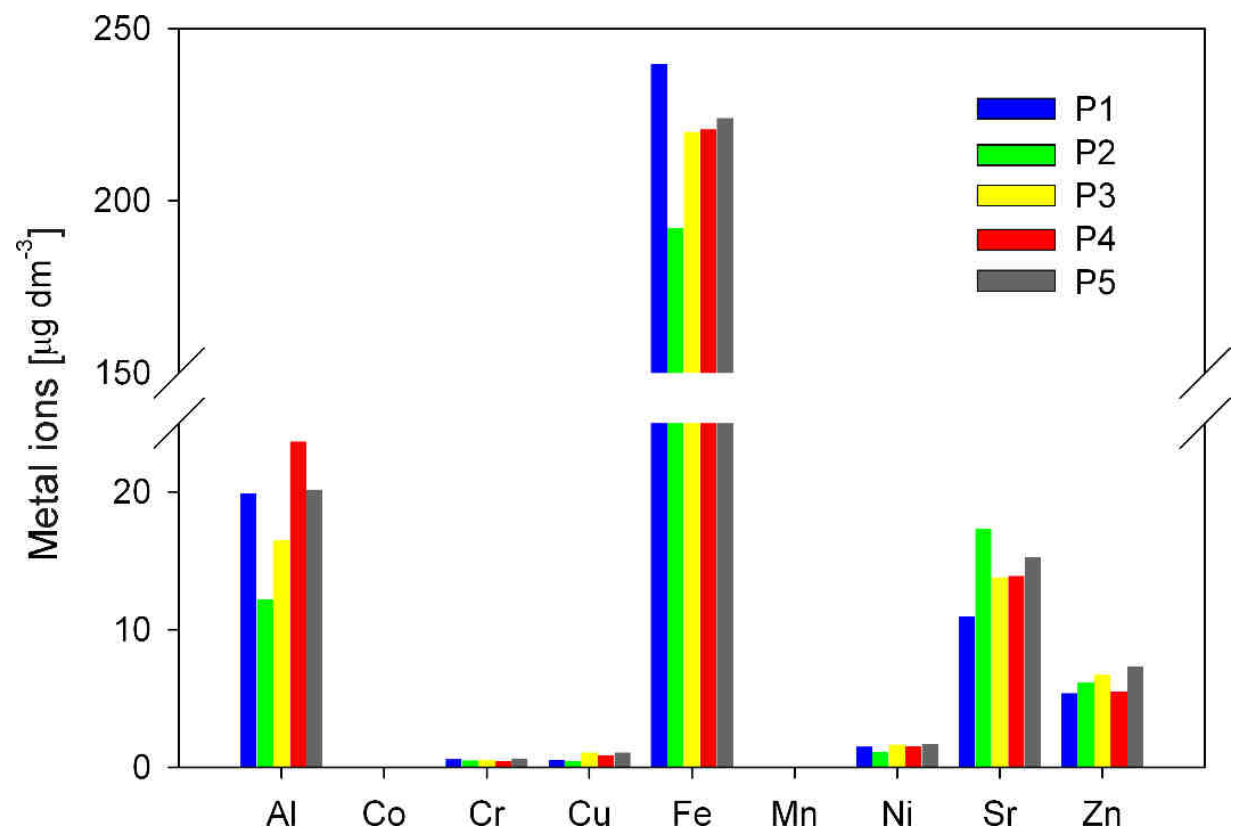

Fig. 5. Average metal ions concentration for the Teesta River

A normalized enrichment factor for metal concentrations above uncontaminated background levels [35] was calculated for the Teesta Reservoir. The water heavy metal values above the reservoir (P2) were taken as the reference values to calculate the enrichment factors for the reservoir center (P3) and below the dam (P4). 
The enrichment $(E F)$ of different metals at the reservoir center $(\mathrm{P} 3)$ was ordered as $\mathrm{Cu}$ $\mathrm{Ni}>\mathrm{Zn}>\mathrm{Cr}>\mathrm{Co}>\mathrm{Sr}$ and the enrichment of different metals below the dam (P4) was ordered as $\mathrm{Cu}>\mathrm{Ni}>\mathrm{Co}>\mathrm{Cr}>\mathrm{Zn}>\mathrm{Sr}$. The largest $E F$ value at both sites was for $\mathrm{Cu}$ with an $E F$ value of 2.75 (minor enrichment) and 2.32 (minor enrichment) at the reservoir center (P3) and below the dam (P4), respectively (Fig. 6). This indicated that $\mathrm{Cu}$ was the most enriched element in the water tested. Lower enrichment indicate $E F$ values for $\mathrm{Ni}: 1.84$ and 1.52 for sites P3 and P4 respectively. Other heavy metals with $E F$ values close to 1.00 at both the reservoir center and below dam belong to the non-enriched group of elements in the study area. This indicated that their sources might be upstream of the reservoir without any additional inputs or that they were insignificantly affected by tributary discharges. The lower $E F$ values below the dam also reflected the water self-purification processes for heavy metals by the reservoir.

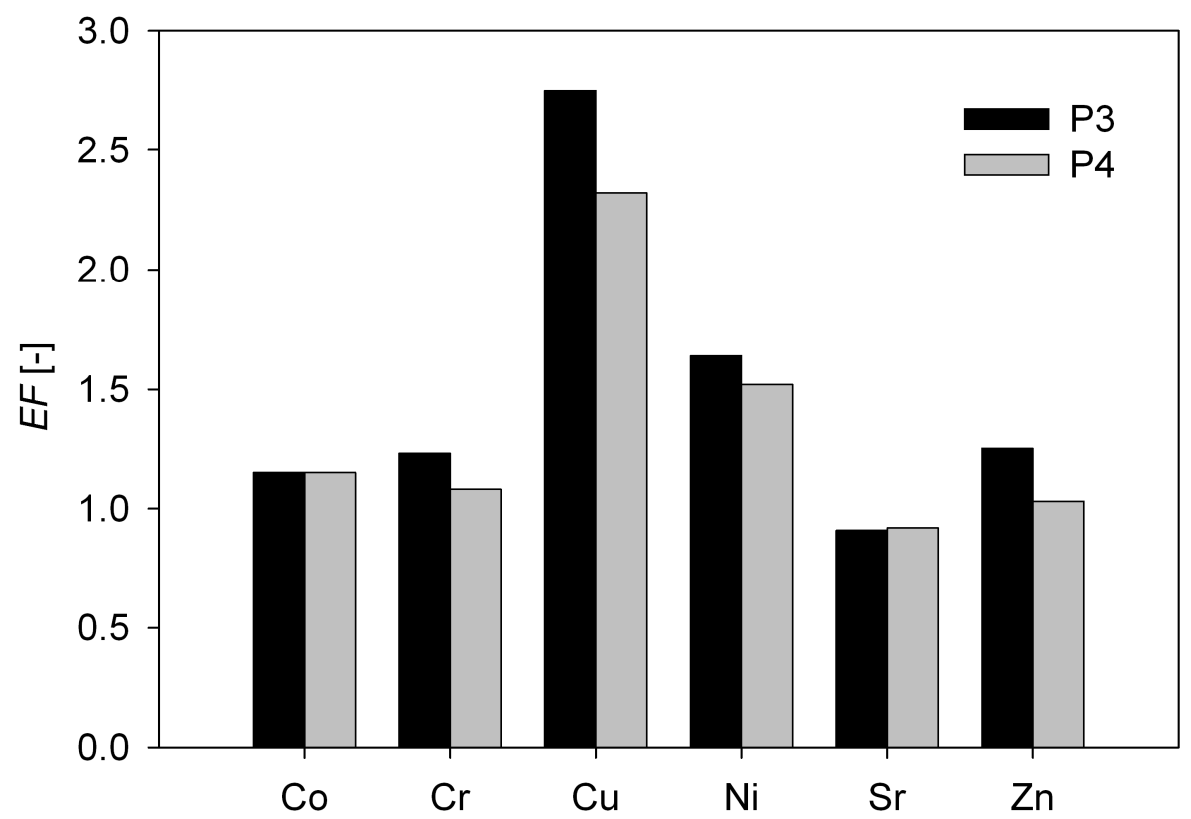

Fig. 6. Average metals ions enrichment factor, $E F$, in the Teesta Reservoir and in the river below the dam

\section{Conclusions}

The analysis of the basic physicochemical properties and chemical composition of the water in the Teesta River in the post-monsoon period, the aim of which was to determine the role of the newly built reservoir in the shaping of the hydrochemical profile of the Himalayan part of the river, enables the following conclusions to be drawn:

1. The Teesta is alkaline in nature. Bicarbonate and $\mathrm{SO}_{4}{ }^{2-}$ are the dominant anions and $\mathrm{Ca}^{2+}$ and $\mathrm{Mg}^{2+}$ are the dominant cations. Rock weathering is the most important mechanism controlling the water chemistry. 
2. A decrease in water temperature caused by the reservoir is slight and amounts to approximately $1.0^{\circ} \mathrm{C}$. A low range of changes indicates that a very weak thermal stratification has developed due to the rapid exchange of water in the reservoir. As for Total Dissolved Solids, marked stabilisation of the values in a narrow range is observed. The values of ANC indicate that there is no risk of acidification along the entire section examined.

3. The newly built reservoir caused decrease most of the basic ions concentrations $\left(\mathrm{Cl}^{-}\right.$, $\mathrm{K}^{+}, \mathrm{Na}^{+}, \mathrm{Mg}^{2+}, \mathrm{NO}_{3}{ }^{-}$and $\left.\mathrm{PO}_{4}{ }^{3-}\right)$. An inverse trend was observed only with respect to $\mathrm{Ca}^{2+}, \mathrm{SO}_{4}{ }^{2-}$ and $\mathrm{NH}_{4}{ }^{+}$. The dam does not influent on the $\mathrm{F}^{-}$concentration.

4. The reservoir causes minor enrichment most of the heavy metals such $\mathrm{Cu}, \mathrm{Ni}, \mathrm{Zn}, \mathrm{Cr}$, $\mathrm{Cd}$ and Sr. The lower enrichment of Teesta water below the dam indicates the water self-purification processes for metals by the Teesta Reservoir.

5. The changes of physicochemical properties and concentrations of ions caused by the reservoir are usually normalised by environmental factors before the Teesta River outlet from the Himalayas (i.e. within $15 \mathrm{~km}$ of the river).

6. The quality of the water tested meets the World Health Organization [46] environmental standards. However, an increase in the concentrations of potentially dangerous metals in the reservoir and water flowing out of it indicates that further monitoring of the Teesta River is necessary.

The results of the study are relevant in light of the construction several reservoirs in the Teesta catchment in the near future, including one located only a dozen kilometres below the reservoir analysed in this study. Further investigations are necessary to determine the direction and scale of hydrochemical changes in the Teesta River caused by a cascade of reservoirs.

\section{Acknowledgments}

This paper is the outcome of research collaboration between Institute of Geography and Spatial Organization, Polish Academy of Science and the Indian National Science Academy.

\section{References}

[1] Chapman DV, editor. Water Quality Assessments: A Guide to the Use of Biota, Sediments, and Water in Environmental Monitoring. London: E \& FN Spon; 1996. https://www.researchgate.net/publication/ 237320993_Water_Quality_Assessments_-_A_Guide_to_Use_of_Biota_Sediments_and_Water_in_ Environmental_Monitoring_-_Second_Edition.

[2] Nikanorov AM, Brazhnikova LV. Water chemical composition of rivers, lakes and wetlands. In: Khublaryan MG, editor. Types and Properties of Water. 2009;2:42-80. http://www.eolss.net/Sample-Chapters/ C07/E2-03.pdf

[3] Ji ZG. Hydrodynamics and Water Quality: Modeling Rivers, Lakes, and Estuaries. $2^{\text {nd }}$ edition. New Jersey: John Wiley Sons; 2017. ISBN: 978-1-118-87715-9

[4] Allan JD, Castillo MM. Stream Ecology: Structure and Function of Running Waters. New York: Springer Sci Business Media; 2007. ISBN 978-1-4020-5583-6.

[5] Hem JD. Study and Interpretation of the Chemical Characteristics of Natural Water. 2254. Department of the Interior, US Geological Survey. 1985. https://pubs.usgs.gov/wsp/wsp2254/pdf/wsp2254a.pdf.

[6] Gao Y, Wang B, Liu X, Wang Y, Zhang J, Jiang Y, et al. Impacts of river impoundment on the riverine water chemistry composition and their response to chemical weathering rate. Frontiers Earth Sci. 2013;7:351-360. DOI: 10.1007/s11707-013-0366-y.

[7] Soja R, Wiejaczka $€$. The impact of a reservoir on the physicochemical properties of water in a mountain river. Water Environ J. 2014;28:473-482. DOI: 10.1111/wej.12059. 
[8] Wiejaczka $Ł$. Reservoir triggered distortion in the relation between water conductivity and river temperature. Water Resour. 2015;42:362-370. DOI: 10.1134/S0097807815030070.

[9] Kijowska-Strugała M, Wiejaczka $Ł$, Kozłowski R. Influence of reservoirs on the concentration of nutrients in the water of mountain rivers. Ecol Chem Eng S. 2016;23(3):413-424. DOI: 10.1515/eces-2016-0029.

[10] Ling TY, Gerunsin N, Soo CL, Nyanti L, Sim SF, Grinang J. Seasonal changes and spatial variation in water quality of a large young tropical reservoir and its downstream river. J Chem. 2017. DOI: $10.1155 / 2017 / 8153246$.

[11] Hannan HH. Chemical modifications in reservoir-regulated streams. In: The Ecology of Regulated Streams. Boston: Springer US; 1979:75-94. DOI: 10.1007/978-1-4684-8613-1_6.

[12] Palmer RW, O'Keeffe JH. Downstream effects of impoundments on the water chemistry of the Buffalo River (Eastern Cape), South Africa. Hydrobiologia. 1990;202:71-83. DOI: 10.1007/BF00027093.

[13] Harrison JA, Maranger RJ, Alexander RB, Giblin AE, Jacinthe PA, Mayorga E, et al. The regional and global significance of nitrogen removal in lakes and reservoirs. Biogeochemistry. 2009;93:143-157. DOI: 10.1007/s10533-008-9272-x.

[14] Rigacci LN, Giorgi AD, Vilches CS, Ossana NA, Salibián A. Effect of a reservoir in the water quality of the Reconquista River, Buenos Aires, Argentina. Environ Monitoring Assess. 2013;185:9161-9168. DOI: 10.1007/s10661-013-3243-y.

[15] Grumbine RE, Pandit MK. Threats from India's Himalaya dams. Science. 2013;339:36-37. DOI: 10.1126/science.1227211.

[16] CISMHE (Centre for Inter Disciplinary Studies of Mountain and Hill Development), Carrying Capacity Study of Teesta Basin in Sikkim. Volume IV: Water Environment. New Delhi: CISMHE; 2006. http://www.actsikkim.com/docs/CCS_IV_Water_Environment.pdf.

[17] Starkel L, Basu S, editors. Rains, Landslides and Floods in the Darjeeling Himalaya. New Delhi: Indian National Science Academy; 2000.

[18] Bookhagen B, Burbank DW. Towards a complete Himalayan hydrological budget: The spatiotemporal distribution of snow melt and rainfall and their impact on river discharge. J Geophys Res-Earth Surf. 2010;115 (F3). DOI: 10.1029/2009jf001426.

[19] Prokop P, Walanus A. Impact of the Darjeeling-Bhutan Himalayan front on rainfall hazard pattern. Natural Hazards. 2017;89:387-404. DOI: 10.1007/s11069-017-2970-8.

[20] Vörösmarty CJ, Fekete BM, Tucker BA. Monthly mean river discharge at gauging station Anderson Bridge. PANGAEA; 2004. DOI: 10.1594/PANGAEA.218327.

[21] Murray JA, Bochin NA. Instructions for compilation of the chapter on catastrophic floods for the UNESCO publication "Annual summary of information on natural disasters". Forms with explanatory notes. Paris: UNESCO; 1973. http://unesdoc.unesco.org/images/0000/000031/003131EB.pdf.

[22] Acharyya SK. Structural framework and tectonic evolution of the Eastern Himalaya. Himalayan Geol. 1980;10:412-439.

https://www.researchgate.net/profile/Subhrangsu_Acharyya/publication/257919243_Structural_framework_ and_tectonic_evolution_of_the_Eastern_Himalaya/links/5782271f08ae69ab88285a34.pdf.

[23] Bhattacharyya K, Mitra G. Geometry and Kinematics of the Darjeeling-Sikkim Himalaya, India: Implications for the Evolution of the Himalayan Fold-Thrust Belt. In: EGU General Assembly Conference Abstracts. 2012;14:4226. DOI: 10.1016/j.jseaes.2015.09.008.

[24] Champion HG, Seth SK. A Revised Survey of Forest Types of India. New Delhi: Manager Publications; 1968. ISBN: 978-8181580610.

[25] Prokop P, Płoskonka D. Natural and human impact on the land use and soil properties of the Sikkim Himalayas piedmont in India. J Environ Manage. 2014;138:15-23. DOI: 10.1016/j.jenvman.2014.01.034.

[26] Wiejaczka Ł, Bucała A, Sarkar S. Human role in shaping the hydromorphology of Himalayan rivers: study of the Tista River in Darjeeling Himalaya. Current Sci. 2014;106:717-724. https://www.researchgate.net/publication/263620718_Human_role_in_shaping_the_hydromorphology_of_H imalayan_rivers_Study_of_the_Tista_River_in_Darjeeling_Himalaya.

[27] Reuss JO, Johnson DW. Acid deposition and the acidification of soils and water. Ecol Stud. 1986;59:1-120.

[28] Bi SP, An SQ, Liu F. A practical application of Driscoll's equation for predicting the acid-neutralizing capacity in acidic natural waters equilibria with the mineral phase gibbsite. Environ Int. 2001;26:327-333. DOI: 10.1016/S0160-4120(01)00008-3.

[29] Hemond HF. Acid neutralizing capacity, alkalinity, and acid-base status of natural waters containing organic acids. Environ Sci Technol. 1990;24:1486-1489. https://stuff.mit.edu/afs/athena/course/1/1.75/www/ Lecture8AlkalinityPaper.pdf.

[30] Eshleman KN, Davies TD, Tranter M, Wigington PJ. A two-component mixing model for predicting regional episodic acidification of surface waters during spring snowmelt periods. Water Resource Res. 1995;31:1011-1021. DOI: 10.1029/94WR03289. 
[31] Driscoll CT, Lawrence GB, Bulger AJ, Butler TJ, Cronan CS, Eagar C, et al. Acidic deposition in the northeastern United States: Sources and inputs, ecosystem effects, and management strategies. Bioscience. 2001;51:180-198. DOI: 10.1641/0006-3568(2001)051[0180:ADITNU]2.0.CO;2.

[32] Kernan MR, Helliwell RC. Partitioning the variation within the acid neutralizing capacity of surface waters in Scotland in relation to land cover, soil and atmospheric depositional factors. Sci Total Environ. 2001;265:39-49. DOI: 10.1016/S0048-9697(00)00648-3.

[33] Sullivan TJ, Cosby BJ, Webb JR, Dennis RL, Bulger AJ, Deviney Jr, FA. Streamwater acid-base chemistry and critical loads of atmospheric sulfur deposition in Shenandoah National Park, Virginia. Environ Monit Assess. 2008;137:85-99. DOI: 10.1007/s10661-007-9731-1.

[34] Kozłowski R, Jóźwiak M. Chemical denudation in a geoecosystem in acid immision conditions. Ecol Chem Eng S. 2013;20(1):41-54. DOI: 10.2478/eces-2013-0003.

[35] Abrahim GMS, Parker RJ. Assessment of heavy metal enrichment factors and the degree of contamination in marine sediments from Tamaki Estuary, Auckland, New Zealand. Environ Monit Assess. 2008;136:227-238. DOI: $10.1007 / \mathrm{s} 10661-007-9678-2$.

[36] Zhao Q, Liu S, Deng L, Yang Z, Dong S, Wang C, et al. Spatio-temporal variation of heavy metals in fresh water after dam construction: a case study of the Manwan Reservoir, Lancang River. Environ Monit Assess. 2012;184:4253-426. DOI: 10.1007/s10661-011-2260-y.

[37] Birch GF, Olmos MA. Sediment-bound heavy metals as indicators of human influence and biological risk in coastal water bodies. ICES. J Marine Sci. 2008;65:1407-1413. DOI: 10.1093/icesjms/fsn139.

[38] Mahanta C, Subramanian V. Water quality, mineral transport and sediment biogeochemistry. In: Singh V, Sharma N, Ojha CSP, editors. The Brahmaputra Basin Water Resources. Vol. 47. Springer Science Business Media. 376-400. 2004. https://link.springer.com/chapter/10.1007/978-94-017-0540-0_21.

[39] Subramanian V. Water quality in south Asia. Asian J Water, Environ Pollut. 2004;1:41-54. https://content.iospress.com/articles/asian-journal-of-water-environment-and-pollution/ajw1-1-2-07.

[40] Singh AK, Mondal GC, Sing, PK, Singh S, Singh TB, Tewary BK. Hydrochemistry of reservoirs of Damodar River basin, India: weathering processes and water quality assessment. Environ Geol. 2005;48:1014-1028. DOI: 10.1007/s00254-005-1302-6.

[41] Singh SK, Sarin MM, France-Lanord C. Chemical erosion in the eastern Himalaya: Major ion composition of the Brahmaputra and $\delta^{13} \mathrm{C}$ of dissolved inorganic carbon. Geochim Cosmochim Acta. 2005;69:3573-3588. DOI: $10.1016 /$ j.gca.2005.02.033.

[42] Piper AM. A graphic procedure in the geochemical interpretation of water analyses. Eos. Transact Amer Geophys Union. 1944;25:914-928. DOI: 10.1029/TR025i006p00914.

[43] Handique S, Sharma P, Baruah KK, Tripathi JK. Spatial and temporal variations in the geochemistry of the Brahmaputra River water. Int J Geosci. 2017;8:756-765. DOI: 10.4236/ijg.2017.85042.

[44] Gibbs RJ. Mechanisms controlling world water chemistry. Science. 1970;170:1088-1090. DOI: 10.1126/science.170.3962.1088.

[45] Galy A, France-Lanord C, Derry LA. The strontium isotopic budget of Himalayan rivers in Nepal and Bangladesh. Geochim Cosmochim Acta. 1999;63:1905-1925. DOI: 10.1016/S0016-7037(99)00081-2.

[46] World Health Organization. Guidelines for Drinking-water Quality. Fourth edition. Geneva:2011. ISBN 9789241548151. http://www.who.int/water_sanitation_health/publications/2011/dwq_guidelines/en/. 